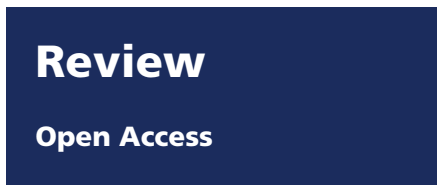

\title{
The heart as an endocrine organ
}

\section{Tsuneo Ogawa and Adolfo J de Bold}

Cardiovascular Endocrinology Laboratory, University of Ottawa Heart Institute, 40 Ruskin Street, Ottawa, Ontario, Canada K1Y 4W7

Correspondence should be addressed to A J de Bold

Email

adebold@ottawaheart.ca

\begin{abstract}
The concept of the heart as an endocrine organ arises from the observation that the atrial cardiomyocytes in the mammalian heart display a phenotype that is partly that of endocrine cells. Investigations carried out between 1971 and 1983 characterised, by virtue of its natriuretic properties, a polypeptide referred to atrial natriuretic factor (ANF). Another polypeptide isolated from brain in 1988, brain natriuretic peptide (BNP), was subsequently characterised as a second hormone produced by the mammalian heart atria. These peptides were associated with the maintenance of extracellular fluid volume and blood pressure. Later work demonstrated a plethora of other properties for ANF and BNP, now designated cardiac natriuretic peptides (cNPs). In addition to the CNPs, other polypeptide hormones are expressed in the heart that likely act upon the myocardium in a paracrine or autocrine fashion. These include the C-type natriuretic peptide, adrenomedullin, proadrenomedullin $\mathrm{N}$-terminal peptide and endothelin-1. Expression and secretion of ANF and BNP are increased in various cardiovascular pathologies and their levels in blood are used in the diagnosis and prognosis of cardiovascular disease. In addition, therapeutic uses for these peptides or related substances have been found. In all, the discovery of the endocrine heart provided a shift from the classical functional paradigm of the heart that regarded this organ solely as a blood pump to one that regards this organ as self-regulating its workload humorally and that also influences the function of several other organs that control cardiovascular function.
\end{abstract}

Endocrine Connections (2014) 3, R31-R44

\section{Historical context}

The phenotype of ventricular cardiomyocytes reflects functions associated with properties inherent to their mechanical task and the conduction of electrical excitation arising from the sino-atrial node. The advent of the electron microscope demonstrated in mammalian atrial cardiomyocytes elements that were previously associated with polypeptide hormone-producing cells. These included abundant rough endoplasmic reticulum, highly developed Golgi complex and storage granules referred to as atrial-specific granules (Fig. 1) $(1,2)$.

The function of these differentiations was not evident and so these findings remained functionally an enigma for 2 decades. In 1981, after developing a number of investigative techniques $(3,4,5,6,7,8)$, de Bold and colleagues demonstrated that injection of atrial muscle extracts to bioassay rats produced a strong natriuresis and diuresis as well as hypotension accompanied by an increase in haematocrit (9). Subsequently, in 1983, a polypeptide named atrial natriuretic factor (ANF) or atrial natriuretic peptide (ANP) was isolated, purified and sequenced from rat atrial extracts $(10,11,12)$. The following year, ANF was isolated from human atria (13). The association of ANF with the atrial-specific granules was demonstrated by both tissue fractionation studies and by immunocytochemistry $(14,15)$. The presence of natriuretic activity in the atria http://www.endocrineconnections.org DOI: 10.1530/EC-14-0012 (c) 2014 The authors Published by Bioscientifica Ltd
This work is licensed under a Creative Commons Attribution 3.0 Unported License. 


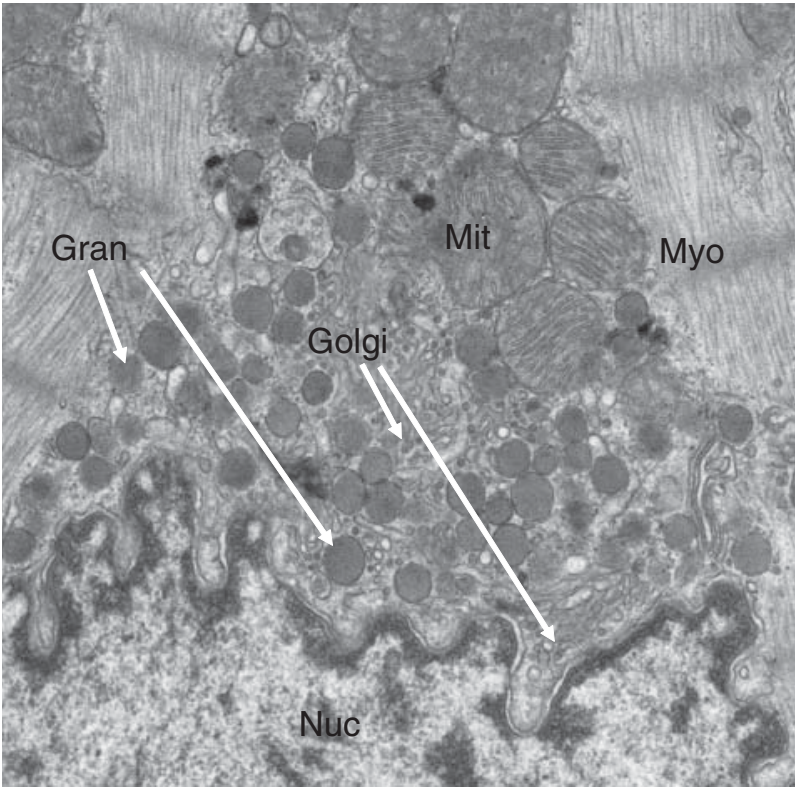

\section{Figure 1}

Transmission electron microscopy of a portion of a mouse atrial cardiomyocyte showing a portion of the nucleus (Nuc) as well as mitochondria (Mit), myofibrils (Myo), Golgi complex (Golgi) and specific atrial granules (Gran). Original magnification: $5000 \times$.

of mammals and in both the atria and ventricles of nonmammalian vertebrates was subsequently demonstrated corresponding with the morphological distribution of atrial specific-like granules in various species (16). These early findings provided the basis to establish the heart as an endocrine organ. Following the discovery of ANF, related peptides such as brain natriuretic peptide (BNP) and C-type natriuretic peptide (CNP) were described thus establishing a natriuretic peptide (NP) family. ANF and BNP are mainly produced in the heart and so they are referred to as cardiac natriuretic peptides (cNPs). Other unrelated peptide hormones such as the calcitonin gene-related peptide (CGRP) family and endothelin-1 (ET1) are also expressed in the heart albeit in quantities that are smaller than in their principal sites of synthesis. Unlike the cNPs that are truly endocrine products, these hormones may act as cardiac paracrine or autocrine agents.

\section{The natriuretic peptide family (ANF, BNP and CNP)}

The NPs share a 17 amino acid ring structure formed by an intra-molecular disulphide linkage (Fig. 2, Table 1). This ring structure is essential for biological activity $(17,18)$. BNP was isolated from porcine brain in 1988. It is a 32-amino acid peptide in humans (18). Although originally isolated from porcine brain, BNP is most abundantly expressed in the atria of the heart. ANF and BNP are functionally considered to be the main endocrine products of the heart. ANF and BNP are co-stored in atrialspecific granules $(15,19)$. A third 'natriuretic' peptide,
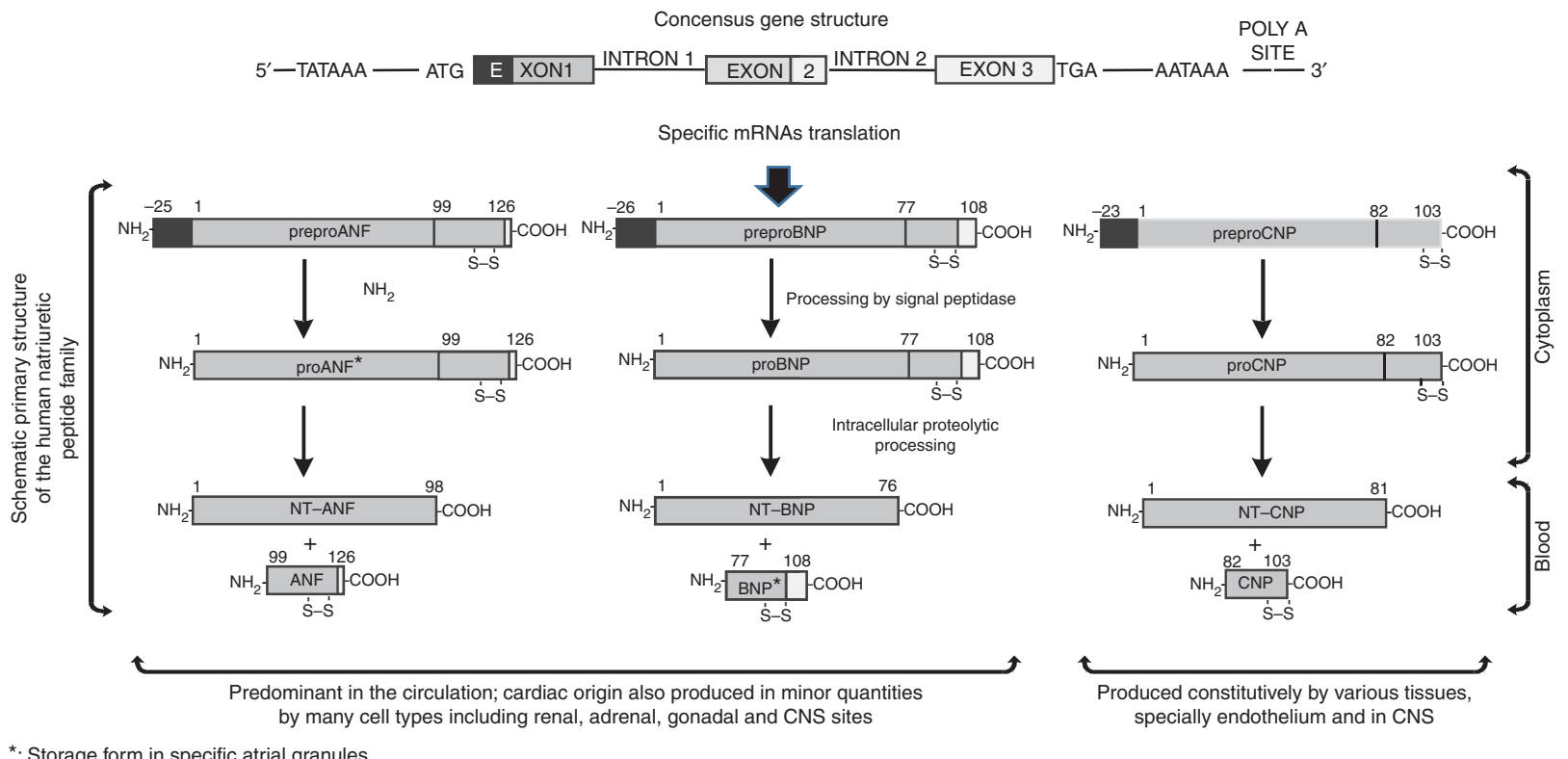

Figure 2

Consensus structure of the natriuretic peptide genes and processing of peptides following translation of the specific mRNAs.

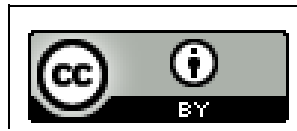

This work is licensed under a Creative Commons Attribution 3.0 Unported License. 
Table 1 Primary structure of various mammalian natriuretic peptides.

\begin{tabular}{|c|c|}
\hline Name & Sequence \\
\hline \multicolumn{2}{|l|}{ ANF } \\
\hline Rat (all rodents) $\mathrm{ANF}_{99-126}$ & $\begin{array}{l}\text { Ser-Leu-Arg-Arg-Ser-Ser-Cys-Phe-Gly-Gly-Arg-Ile-Asp-Arg-Ile-Gly-Ala-Gln-Ser-Gly- } \\
\text { Leu-Gly-Cys-Asn-Ser-Phe-Arg-Tyr }\end{array}$ \\
\hline Human, canine, bovine $\mathrm{ANF}_{99-126}$ & $\begin{array}{l}\text { Ser-Leu-Arg-Arg-Ser-Ser-Cys-Phe-Gly-Gly-Arg-Met-Asp-Arg-Ile-Gly-Ala-Gln-Ser-Gly- } \\
\text { Leu-Gly-Cys-Asn-Ser-Phe- Arg-Tyr }\end{array}$ \\
\hline Urodilatin: ANF $_{99-126}$ & $\begin{array}{l}\text { Thr-Ala-Pro-Arg-Ser-Leu-Arg-Arg-Ser-Ser-Cys-Phe-Gly-Gly-Arg-Met-Asp-Arg-Ile-Gly- } \\
\text { Ala-GIn-Ser-Gly-Leu-Gly-Cys-Asn-Ser-Phe- Arg-Tyr }\end{array}$ \\
\hline \multicolumn{2}{|r|}{ 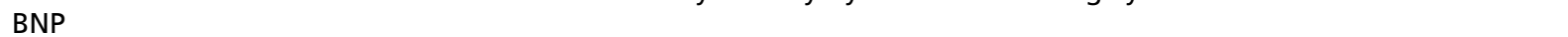 } \\
\hline Rat $\mathrm{BNP}_{51-95}$ & $\begin{array}{l}\text { Ser-Gln-Asp-Ser-Ala-Phe-Arg-Ile-Gln-Glu-Arg-Leu-Arg-Asn-Ser-Lys-Met-Ala-His-Ser- } \\
\text { Ser-Ser-Cys-Phe-Gly-GIn-Lys-Ile-Asp-Arg-Ile-Gly-Ala-Val-Ser-Arg-Leu-Gly-Cys-Asp- } \\
\text { Gly-Leu-Arg-Leu-Phe }\end{array}$ \\
\hline Human $\mathrm{BNP}_{77-108}$ & $\begin{array}{l}\text { Ser-Pro-Lys-Met-Val-Gln-Gly-Ser-Gly-Cys-Phe-Gly-Arg-Lys-Met-Asp-Arg-Ile-Ser-Ser- } \\
\text { Ser-Ser-Gly-Leu-Gly-Cys-Lys-Val-Leu-Arg-Arg-His }\end{array}$ \\
\hline Canine $\mathrm{BNP}_{74-105}$ & $\begin{array}{l}\text { Ser-Pro-Lys-Met-Met-His-Lys-Ser-Gly-Cys-Phe-Gly-Arg-Arg-Leu-Asp-Arg-Ile-Gly-Ser- } \\
\text { Leu-Ser-Gly-Leu-Gly-Cys-Asn-Val-Leu-Arg-Lys-Tyr }\end{array}$ \\
\hline Mouse $\mathrm{BNP}_{77-121}$ & $\begin{array}{l}\text { Ser-Gln-Gly-Ser-Thr-Leu-Arg-Val-GIn-GIn-Arg-Pro-Gln-Asn-Ser-Lys-Val-Thr-His-Ile- } \\
\text { Ser-Ser-Cys-Phe-Gly-His-Lys-Ile-Asp-Arg-Ile-Gly-Ser-Val-Ser-Arg-Leu-Gly-Cys-Asn- } \\
\text { Ala-Leu-Lys-Leu-Leu }\end{array}$ \\
\hline Porcine $\mathrm{BNP}_{75-106}$ & $\begin{array}{l}\text { Ser-Pro-Lys-Thr-Met-Arg-Asp-Ser-Gly-Cys-Phe-Gly-Arg-Arg-Leu-Asp-Arg-Ile-Gly-Ser- } \\
\text { Leu-Ser-Gly-Leu-Gly-Cys-Asn-Val-Leu-Arg-Arg-Tyr }\end{array}$ \\
\hline \multicolumn{2}{|r|}{ ( } \\
\hline Human, rat, porcine $\mathrm{CNP}_{82-103}$ & $\begin{array}{l}\text { Gly-Leu-Ser-Lys-Gly-Cys-Phe-Gly-Leu-Lys-Leu-Asp-Arg-Ile-Gly-Ser-Met-Ser-Gly-Leu- } \\
\text { Gly-Cys }\end{array}$ \\
\hline Porcine $\mathrm{CNP}_{51-103}$ & $\begin{array}{l}\text { Asp-Leu-Arg-Val-Asp-Thr-Lys-Ser-Arg-Ala-Ala-Trp-Ala-Arg-Leu-Leu-Glu-Glu-His-Pro- } \\
\text { Asn-Ala-Arg-Lys-Tyr-Lys-Gly-Ala-Asn-Lys-Lys-Gly-Leu-Ser-Lys-Gly-Cys-Phe-Gly-Leu- } \\
\text { Lys-Leu-Asp-Arg-Ile-Gly-Ser-Met-Ser-Gly-Leu-Gly-Cys }\end{array}$ \\
\hline
\end{tabular}

$\mathrm{CNP}$, is a 22-amino acid peptide isolated from porcine brain in 1990. It lacks the carboxyl terminal of ANF and BNP and hence it lacks natriuretic properties (20). CNP is produced in a constitutive manner in the brain and pituitary gland, and also in the endothelium, smooth muscle cells of the intima, media and vasa vasorum of arteries and in macrophages in normal and atheromatous coronary arteries in humans $(20,21,22)$. Although initial investigations failed to find CNP in the heart (23), its presence was subsequently shown by RIA, immunocytochemistry and RT-PCR (24). The C-terminal portions of human $\mathrm{ANF}$ and BNP: $\mathrm{ANF}_{99-126}$ and $\mathrm{BNP}_{77-108}$ are the biologically activepeptides derived from processing proANF and proBNP by cardiomyocytes before release into the circulation.

Plasma levels of ANF and BNP in normal subjects are $3.2-19.5$ and $1.4-14.5 \mathrm{pmol} / \mathrm{l}$ respectively $(25,26)$. The greater part of ANF and BNP gene expression in mammals is found in the atria of the heart. Other sites, such as the cardiac ventricles, aortic arch as well as extra cardiac sites including hypothalamus, pituitary gland and lung also produce cNPs at much lower levels than the atria $(27,28,29)$.

Although it is often mentioned that BNP is a ventricular hormone while ANF is viewed as an atrial hormone, this concept needs to be reconsidered. In certain pathophysiological conditions, ANF and BNP plasma levels increase significantly and while ANF remains higher than BNP, the latter increases only relatively more than ANF $(30,31,32)$.

The biochemical evidence supports an overwhelming atrial source of cNPs. The ANF concentration in normal subjects in atrium and ventricle is 9600 and $37 \mathrm{pmol} / \mathrm{g}$ respectively, while the BNP concentration of normal subjects in atrium and ventricle is 250 and $18 \mathrm{pmol} / \mathrm{g}$ respectively (33). Even taking into account the differences in mass between the atrial and ventricular chambers, it is not possible to conclude that BNP is a ventricular hormone. Similar conclusions can be reached when evaluating transcript and peptide abundance for atrial and ventricular ANF and BNP $(32,34)$.

Cardiac catheterisation data in humans with left ventricular hypertrophy showed that the abnormal circulating levels of cNPs are significantly derived from atrial sources (35). Replacement of the failing ventricle in orthotropic heart transplantation in human does not result in normalisation of either BNP or ANF plasma levels even after normalisation of the intracardiac pressures and the renin-angiotensin-aldosterone system (30). From the pathophysiological point of view, these findings show that http://www.endocrineconnections.org DOI: 10.1530/EC-14-0012
(C) 2014 The authors Published by Bioscientifica Ltd
This work is licensed under a Creative Commons Attribution 3.0 Unported License. 
while there may be a good correlation between parameters, such as ventricular hypertrophy or failure or ischemic events and cNPs secretion, this secretion may not be considered of ventricular origin.

Both ANF and BNP are synthesised in and secreted from the atria in a regulated manner. In ventricles, given the practical absence of granules in the bulk of the muscle, the minute amounts secreted are said to occur via the constitutive pathway (19). However, this has never been formally demonstrated.

ANF and BNP are continuously secreted from the atria under basal conditions. Mechanical stretch of atrial muscle increases the rate of peptide secretion rapidly followed by a sharp decline to baseline. This transient increased secretion of ANF and BNP is not due to the cNPs pool depletion but due to the decreased sensitivity to the stimulating signal for regulated release (36). ET1 and phenylephrine (PE) also increase ANF and BNP secretion, but the rate of increase and decline in the secretion are more gradual compared with mechanical stretch $(37,38,39)$. The protein synthesis inhibitor cycloheximide partially but not completely abolishes basal cNP secretion (36), but Monensin, an ionophore that impairs protein sorting and transport in the trans-Golgi network and that inhibits vesicle formation without directly affecting protein synthesis, completely inhibited stimulated secretion without affecting baseline release. Double-label pulse-chase analysis showed that cardiomyocytes preferentially release newly synthesised hormone in a manner that does not entirely rely on protein synthesis (40). These findings suggest that a constitutive-like release, which is based on an exocytosis of vesicles budding from immature granules, is the main release mechanism of operation in atrial cardiomyocytes. Constitutive-like release is independent of the regulated and constitutive pathways (41).

Many of the agonists of cNPs secretion, such as ET1, angiotensin II (AII) and PE, signal through the receptors coupled to $\mathrm{Gq}$ proteins, although other subclasses may also be used $(42,43)$ and stimulate the RAS/c-Raf- 1 and the phosphoinositide signalling pathways leading to the recruitment and activation of effector molecules such as those found in MAP kinase cascades $(44,45)$. Gi/o inhibition by pertussis toxin (PTX) abolishes stretchsecretion coupling without affecting baseline secretion through a mechanism that is independent of Gq signalling, suggesting that PTX sensitive Gi/o proteins are involved in stretch-induced secretion in atria. By immunocytochemistry, ANF and G $\alpha \mathrm{O}$ are seen co-localised in atrial granules, suggesting a role for this $G$ protein in the secretion of ANF and its sensitivity to PTX (46).
An involvement of glucagon-like peptide-1 (GLP1) has recently been implicated in the regulation of ANF secretion from the heart. GLP1 is one of the incretin hormones secreted from endocrine cells located in the epithelium of the small intestine. Glucose-stimulated incretin is carried through the circulation to the pancreatic $\beta$ cells where it stimulates insulin secretion. Blood pressure reduction has been reported in type-2 diabetic patients treated with GLP1 analogues or dipeptidyl peptidase- 4 enzyme inhibitors $(47,48)$. Gene expression of the cardiac GLP1 receptor was detected in atria but not in ventricles. GLP1 receptor activation promoted ANF secretion and blood pressure reduction. These effects were not seen in GLP1 receptor knockout mice or ANF knockout mice (49). These data suggest that an increase in ANF secretion from the atria is at least partly involved in the antihypertensive effect of GLP1 receptor agonists.

The biological effects of ANF and BNP are predominantly mediated through the NPR-A receptor, a guanylyl cyclase-coupled receptor, that is widely distributed throughout the body, including the kidneys, vascular smooth muscle, adrenals, brain and heart $(50,51)$. NPR-B, a second guanylyl cyclase-coupled receptor, is associated with CNP signalling. Five domains are recognised in NPR-A and NPR-B: an extracellular ligand-binding domain that binds NP, a short transmembrane domain, a kinase homology domain, a dimerisation domain and a guanylyl cyclase domain (52). Binding of agonists to the NP receptors results in an increase in intracellular cGMP that can spill over to the general circulation. Systemic administration of ANF elevates urinary and circulating levels of cGMP (53).

Intracellular cGMP targets several enzymes and ion channels including cGMP-dependent protein kinases, cGMP-gated ion channels and cGMP-regulated cyclic nucleotide phosphodiesterases (54). Changes in the activity of these enzymes or channels result in a vasorelaxant effect, inhibition of $\mathrm{Na}^{+}$reabsorption in renal inner medullary collecting ducts and in various other effects such as modulation of steroidogenesis in the adrenal glands and phototransduction $(55,56)$.

A third natriuretic peptide receptor, NPR-C, is considered to be a clearance receptor, although G-protein signalling has been associated with it (57). The short 37-amino acid cytoplasmic segment of NPR-C is characteristic of several receptors involved in peptide and macromolecule clearance. NPR-C is found most abundantly in the glomerular and vascular structures of the kidney, and also in the adrenals, lungs, brain, heart and the vascular wall $(58,59)$.

This work is licensed under a Creative Commons Attribution 3.0 Unported License. 
The binding potency of the NPRs is ranked as follows: $\mathrm{NPR}-\mathrm{A}=\mathrm{ANF} \geq \mathrm{BNP}>\mathrm{CNP} ; \quad \mathrm{NPR}-\mathrm{B}=\mathrm{CNP} \geq \mathrm{ANF}>\mathrm{BNP}$; $\mathrm{NPR}-\mathrm{C}=\mathrm{ANF} \geq \mathrm{CNP}>\mathrm{BNP}(60)$.

From the haemodynamic point of view the endocrine heart serves to regulate cardiac preload and afterload due to its influence in the regulation of extracellular fluid volume mediated by targets such as the kidney, the reninangiotensin-aldosterone system and arterial and sympathetic tones. However, many other targets have been characterised (for a review see 61, 62, 63).

In the kidneys ANF and BNP increase glomerular infiltration rate and filtration fraction by dilating afferent arterioles and constricting efferent arterioles leading to an increase in glomerular capillary hydraulic pressure that enhances the driving force for ultrafiltration. ANF and BNP also inhibit $\mathrm{Na}^{+}$reabsorption at the level of the renal collecting duct $(64,65)$. These renal functions of ANF and BNP underlie their acute strong diuretic and natriuretic effects.

ANF and BNP have multiple actions on nerve activity. ANF reduces cardiac and pulmonary chemo- and baroreceptor activity, which leads to the suppression of sympathetic outflow to the heart. A decrease in sympathetic activity together with the increase in vagal afferent activity leads to a reduction in heart rate and cardiac output (66). ANF and BNP reduce vascular smooth muscle tone and peripheral vascular resistance and also decrease salt and water appetite, thus leading to a reduction in extracellular fluid volume (67). ANF inhibits secretion of vasopressin from the posterior pituitary leading to decreases in water reabsorption in the collecting duct of the kidney (68).

The cNPs possess growth-suppressing and antiproliferative properties. Growth promoting effects generated by norepinephrine are inhibited by ANF treatment on both cardiomyocytes and fibroblasts (69). BNP inhibits cardiac intersitium remodelling through its antifibrotic effects (70) and also inhibits transforming growth factor-induced fibrosis in association with cGMP-dependent protein kinase and the MEK/ERK pathway (71). ANF antagonises the growth of vascular smooth muscle cells (72) and promotes endothelial cell function in atherosclerosis (73).

cNPs antagonise the renin-angiotensin-aldosterone system by inhibiting aldosterone synthesis and secretion, and by suppressing renin release $(74,75,76)$.

cNPs exert potent lipolytic effects in isolated human fat cells as well as in preadipocytes through cGMPmediated phosphorylation $(77,78,79,80,81)$. Cardiac cachexia often seen in the heart failure, during which ANF and BNP are increased, may be partly explained by the lipolytic effects of cNPs. Finally, ANF inhibits the proliferation of human visceral preadipocytes (82).

A change in haemodynamic load or neurohumoral stimulation can lead to increase cNPs synthesis and/or secretion. The endocrine heart responds differently to haemodynamic loads, depending on whether the challenge is acute (hours), subacute ( $24 \mathrm{~h}$ to 1 week) or chronic (longer than a week).

The increased secretion of cNPs following acute mechanical atrial stretch is based on a phenomenon referred to as stretch-secretion coupling (83). This event is characterised by a phasic, short-term burst of cNPs secretion with no apparent effect on synthesis (44). In stretch-secretion coupling, the predominant circulating cNPs source is the existing atrial NPs pool.

Subacute haemodynamic load is observed during mineralocorticoid escape, which is characterised by a transient period of positive sodium balance resulting from chronic exposure to mineralocorticoid excess followed by a vigorous natriuresis leading to a new steady-state of sodium balance. The increase in intravenous volume and central venous pressure leads to increased ANF and BNP production in atria but not in ventricles, in which plasma ANF but not BNP is significantly elevated. In subacute haemodynamic load, the predominant circulating cNP source is a stored hormone plus newly synthesised hormone (44).

Both, atria and ventricles increase synthesis and secretion of ANF and BNP during chronic haemodynamic overload. This condition is seen in chronic arterial hypertension and chronic congestive heart failure and is accompanied by the ventricular re-expression of the cardiac foetal gene programme, which includes the re-expression of both ANF and BNP $(28,32)$. The main source of cNPs, however, remains the cardiac atria, despite a significant increase in the cNPs content in the ventricles is also observed.

In addition to mechanical stimuli, circulating neuroendocrine agents can act on atrial cardiomyocytes to modulate cNP synthesis and secretion. These include ET1, hydroxyvitamin $\mathrm{D}_{3}$, glucocorticoids, thyroid hormones, several growth factors, thrombin, AII, prostaglandins and $\alpha_{1}$-adrenergic agents $(34,84,85,86,87)$. The proinflammatory cytokines such as TNF $\alpha$ and IL1 $\beta$ and lipopolysaccharide stimulate the synthesis and secretion of BNP specifically $(88,89)$.

cNPs blood levels are increased in various pathological conditions such as heart failure, myocardial infarction, hypertension, left ventricular hypertrophy and pulmonary hypertension $(90,91,92,93,94,95,96,97,98)$.

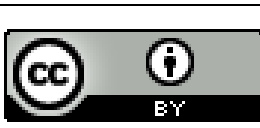


Determination of these levels is useful in the diagnosis and prognosis of these cardiovascular pathologies. In addition to $\mathrm{ANF}_{99-126}$ and $\mathrm{BNP}_{77-108}$, the biologically inactive N-terminal fragments of the cNP prohormones, NT-proANF and NT-proBNP, also circulate in plasma. As these N-terminal fragments are more stable in the circulation and their half-lives are longer than those of the C-terminal prohormones $(99,100)$ the usefulness of NT-proANF and NT-proBNP as biomarkers of disease has been extensively investigated. BNP has been found to perform somewhat better than ANF and NT-proANF $(101,102,103)$ in diagnosis and prognosis. NT-proBNP and BNP provide interchangeable information, although NT-proBNP seems to perform better in diagnosing mild heart failure or asymptomatic left ventricular dysfunction (104). At present BNP and NT-proBNP are established diagnostic biomarkers for heart failure $(105,106)$, ventricular remodelling after acute myocardial infarction (96, 107), left ventricular hypertrophy $(103,108)$ and pulmonary hypertension (109).

An immunoassay that detects the midregional fragment of proANF (MR-proANP) has been developed (110). In a study in 797 chronic congenital heart failure patients, MR-proANP outperformed BNP and NT-proBNP in the prediction of death (111). In another study of 251 patients with dyspnoea, BNP and MR-proANP provided similar diagnostic information and were clinically useful as an aid in the diagnosis of acutely decompensated heart failure (112).

Because the cNPs possess diuretic, natriuretic and hypotensive activity, ANF and BNP have been used in the treatment of various cardiovascular conditions. As ANP and BNP bind to the same receptor, NPR-A, it would be expected that the therapeutic effects of these peptides would be similar, but some differences between ANF and BNP are apparent in the clinical settings. The infusion of carperitide, a recombinant form of human ANF, improved congestive heart failure and acute myocardial infarction, and also had renal protective effects on contrast-induced nephropathy $(113,114,115,116)$. However, the effect and safety of nesiritide, a recombinant form of BNP, has been questioned. According to one study, the infusion of nesiritide to heart failure patients increased the risk of worsening renal function (117). Other trials with nesiritide in heart failure patients did not show any changes regarding death rate, re-hospitalisation rate and renal function, and hence the routine use of nesiritide to acute failure patients was not recommended (118). In another study, s.c. administration of BNP twice a day for 8 weeks improved haemodynamics in heart failure patients with preserved glomerular filtration rate (119).
The third member of NP family, CNP, is produced within the heart in a constitutive-like manner. Plasma CNP levels are 1-6 pmol/l, which is one-third of those for ANF $(120,121)$. High concentrations of CNP are found in the CNS, especially in the pituitary gland (21). Relatively low levels of CNP are found in kidneys, bone, blood vessels and heart (122). The CNP concentration in atrium is $0.11 \pm 0.018 \mathrm{pmol} / \mathrm{g}$, which is 100 times less than that found in the CNS (120). In the cardiovascular system, CNP gene expression is found mainly in endothelial cells and to some extent in cardiomyocytes and cardiac fibroblasts $(24,123,124,125)$. Blood samples taken during cardiac catheterisation in patients with congestive heart failure, show that CNP plasma levels in the coronary sinus is significantly higher than that in aorta, suggesting that CNP is synthesised in the human heart $(125,126)$. CNP secretion from endothelial cells is stimulated by various cytokines, such as transforming growth factor, tumour necrosis factor and interleukin-1 $(123,127)$. ANF and BNP also stimulate the synthesis and secretion of CNP in endothelial cells (128).

CNP possesses potent vasodilating properties on isolated blood vessels and produces growth inhibition of vascular smooth muscle cells $(129,130)$. NPR-B gene expression is observed in vascular smooth muscle, suggesting that CNP acts locally to inhibit vasoconstriction and vascular growth. CNP also has direct effects on cardiac function where it acts initially as a positive inotropic and lusitropic agent followed by a negative inotropic effect in the isolated heart $(131,132,133)$. CNP inhibits ET1-induced cardiomyocyte hypertrophy via a cGMP-dependent mechanism (134) as well as interstitial fibrosis and collagen I and III gene expression in chronically Ang II-infused mice (135).

I.v. administration of CNP to healthy volunteers decreased blood pressure with an increase in diuretic and natriuretic activities in doses ten times higher than those used to compare it with ANF (136). In congestive heart failure, plasma levels and atrial concentration of CNP are increased $(121,137)$. It is assumed that in volume overload, the increased ANF and BNP together with the pro-inflammatory cytokines stimulate the synthesis of CNP in heart, which in turn exerts local vasodilation and inhibits vascular growth and cardiac hypertrophy.

\section{Adrenomedullin and related peptides}

Adrenomedullin (AM) is a 52-amino acid peptide first isolated from human pheochromocytoma in 1993 (138). The structure of AM makes it a member of the calcitonin

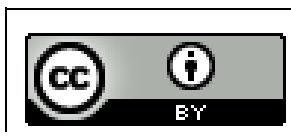

This work is licensed under a Creative Commons Attribution 3.0 Unported License. 
superfamily, which includes CGRP, calcitonin and amylin. AM contains a six-amino acid ring structure formed by disulphide bond and an amidated C-terminal tyrosine residue, both of which are essential for biological activity.

A unique 20 residue sequence followed by Gly-LysArg, a typical amidation signal, exists in the N-terminal region of preproadrenomedullin that was found in human pheochromocytoma (139). This peptide was named proadrenomedullin N-terminal 20 peptide (PAMP) and shows no similarity with any other peptides.

Plasma level of AM is $2-10 \mathrm{pmol} / \mathrm{l}$, which is comparable with ANF plasma levels $(140,141)$. In human, highest gene expression and highest-immunoreactive $A M$ is seen in adrenal medulla, which is more than ten times higher than in ventricle or atria (142). AM gene expression is also seen in cardiomyocytes, cardiac fibroblasts, vascular endothelial cells and smooth muscle cells $(143,144,145)$. A large part of plasma $A M$ originates from the endothelial cells in various organs (146).

$A M$ binds to three types of receptors structurally made of two components: one is a calcitonin receptor-like receptor and the other one is denominated receptor activity-modifying protein (147). These receptors are coupled to $G$ protein and adenylyl cyclase.

AM possesses a wide spectrum of biological actions such as vasodilation, natriuresis and diuresis (148) as well as the inhibition of proliferation of cardiac fibroblasts and the production of extracellular matrix (149).

Plasma AM is increased in various pathological condition such as essential hypertension, acute coronary syndrome, congestive heart failure and septic shock $(150,151,152,153,154)$. The increased production of cardiac AM is believed to have a cardio protective effect by decreasing pressure overload, cardiac mass as well as fibrosis.

Although both the cNPs and AM possess hypotensive, diuretic and natriuretic properties, the precise regulation of circulating levels of these peptides might be different because cNPs are synthesised mainly in heart, whereas the principal production sites of AM are blood vessels and adrenal medulla.

\section{Proadrenomedullin $\mathbf{N}$-terminal 20 peptide}

Plasma level of PAMP is $0.1-1.0 \mathrm{pmol} / \mathrm{l}$, which is $10-20 \%$ of plasma AM concentration $(139,141,155)$. The highest concentration of PAMP is seen in adrenal medulla at $13.8 \pm 7.9 \mathrm{pmol} / \mathrm{g}$. A relatively high concentration of PAMP is detected in atria of the heart and low levels in ventricles, lungs and kidneys (139).
PAMP is a potent hypotensive peptide. The blood pressure lowering mechanism is different from that of AM (156). AM reduces vascular tone while PAMP reduces sympathetic tone (157). Further, PAMP does not affect protein synthesis in cardiomyocytes or cardiac fibroblasts (159).

Similarly to AM, plasma levels of PAMP are increased in patients with a variety of diseases such as essential hypertension, congestive heart failure, chronic renal failure and septic shock $(140,155,159,160)$. This is to be expected given that PAMP and AM are processing products from the same precursor.

\section{Endothelin-1}

The 21-amino acid peptide ET was first isolated from the conditioned medium of cultured endothelial cells and then sequenced in 1988 (161). Shortly after, two structurally similar peptides differing by two and six amino acids were identified. Altogether, the peptides were designated ET1, -2 and -3 respectively $(162,163)$. ET1 is the predominant isoform and biologically most relevant (164). Plasma level of ET1 is 2-6 pmol/1. The highest concentration of ET1 is found in blood vessels (endothelium) $(165,166)$. To a lesser extent, ET1 expression is found in other tissues including cardiomyocytes, vascular smooth muscle cells and kidney $(167,168)$.

ET1 produces a potent and long-lasting vasoconstriction resulting in an increase in blood pressure (161). ET1 also has a direct positive inotropic and chronotropic effects on heart muscle (169). In cultured human cardiac fibroblast, ET1 elicits collagen synthesis. ET1 stimulates the secretion and synthesis of ANF and BNP in heart $(39,170,171)$.

There are two types of G-protein-coupled receptors for ET: ETA and ETB (172). ET1 exerts a vasoconstricting and growth-promoting action through the ETA receptor found in smooth muscle cells. Through the ETB receptor located in endothelial cells, ET1elicits vasodilation mediated by nitric oxide (173).

ET1 production is stimulated by hypoxia, angiotensin II, cytokines, growth factors and reduced by nitric oxide and ANF $(174,175,176,177,178,179,180)$. ET1 plasma levels are increased in congestive heart failure, myocardial infarction, pulmonary hypertension and renal failure. Several findings suggest that ET1 produced locally in the heart may have hypertrophic and fibrotic effects, thus contributing to cardiac remodelling $(181,182,183)$.

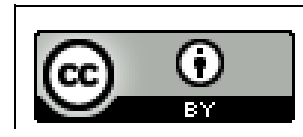

This work is licensed under a Creative Commons Attribution 3.0 Unported License. 


\section{Conclusion}

The heart as an endocrine organ owes its designation to the secretory phenotype of mammalian atrial cardiomyocytes that is associated with the production of the natriuretic polypeptide hormones ANF and BNP. In nonmammalian vertebrates, as well as in the mammalian fetus, the secretory phenotype is displayed by both atrial and ventricular cardiomyocytes. It should be noted that cardiomyocytes in the ventricular conduction system of mammals also display a secretory phenotype.

Cells in the heart also express other polypeptide hormones and their receptors, such as AM and ET1. The expression levels of these hormones in the heart are increased in various cardiovascular pathologies such as hypertension, cardiac hypertrophy, congestive heart failure and acute coronary syndrome. Whether these hormones spill over to contribute to the observed increases in plasma levels is often not clear so that the locally synthesised hormones may be viewed as acting locally within the heart in a paracrine and/or autocrine fashion.

In terms of overall properties of hormones found in the heart, those belonging to the natriuretic peptide family or AM-related peptides have hypotensive, natriuretic and diuretic properties. Many of these peptides also have anti-proliferative and anti-fibrotic properties and thus may be involved in preventing cardiac remodelling. On the other hand, ET1 has hypertensive, volume retentive, and hypertrophic properties that while essential for maintaining cardiovascular homeostasis in cases of massive haemorrhage or hypotensive conditions, can lead to hypertrophic or fibrotic changes in the heart under protracted action.

Regardless of whether their main site of production is cardiac or not, the polypeptide hormones mentioned above appear to contribute cooperatively to regulate cardiovascular haemodynamics through their actions on vascular tone, autonomic nerve activity and cardiac mass in both health and disease.

\section{Declaration of interest}

The authors declare that there is no conflict of interest that could be perceived as prejudicing the impartiality of the review.

\section{Funding}

Supported by grants from the Ontario Heart and Stroke Foundation of Ontario and the Canadian Institutes of Health Research.

\section{References}

1 Kisch B. A significant electron microscopic difference between the atria and the ventricles of the mammalian heart. Experimental Medicine and Surgery 196321 193-221.

2 Jamieson JD \& Palade GE. Specific granules in atrial muscle cells. Journal of Cell Biology 196423 151-172. (doi:10.1083/jcb.23.1.151)

3 de Bold AJ. Morphometric assessment of granulation in rat atrial cardiocytes: effect of age. Journal of Molecular and Cellular Cardiology 197810 717-724. (doi:10.1016/0022-2828(78)90406-6)

4 de Bold AJ, Raymond JJ \& Bencosme SA. Atrial specific granules of the rat heart: light microscopic staining and histochemical reactions. Journal of Histochemistry and Cytochemistry 197826 1094-1102. (doi:10.1177/26.12.83339)

5 de Bold AJ \& Bencosme SA. Selective light microscopic demonstration of the specific granulation of the rat atrial myocardium by leadhematoxylin-tartrazine. Stain Technology 197550 203-205.

6 de Bold AJ \& Bencosme SA. Studies on the relationship between the catecholamine distribution in the atrium and the specific granules present in atrial muscle cells: 1. Isolation of a purified specific granule subfraction. Cardiovascular Research 1973 7 351-363. (doi:10.1093/cvr/ 7.3.351)

7 de Bold AJ \& Bencosme SA. Autoradiographic analysis of label distribution in mammalian atrial and ventricular cardiocytes after exposure to tritiated leucine. In Recent Advances in Studies on Cardiac Structure and Metabolism. The Cardiac Sarcoplasm. Eds P-E Roy \& P Harris. Baltimore, MD, USA: University Park Press, 1975.

8 de Bold AJ. Heart atria granularity effects of changes in waterelectrolyte balance. Proceedings of Society Experimental Biology and Medicine 1979161 508-511. (doi:10.3181/00379727-161-40584)

9 de Bold AJ, Borenstein HB, Veress AT \& Sonnenberg H. A rapid and potent natriuretic response to intravenous injection of atrial myocardial extracts in rats. Life Sciences 198128 89-94. (doi:10.1016/ 0024-3205(81)90370-2)

10 de Bold AJ \& Flynn TG. Cardionatrin I - a novel heart peptide with potent diuretic and natriuretic properties. Life Sciences 198333 297-302. (doi:10.1016/0024-3205(83)90390-9)

11 Flynn TG, de Bold ML \& de Bold AJ. The amino acid sequence of an atrial peptide with potent diuretic and natriuretic properties. Biochemical and Biophysical Research Communications 1983117 859-865. (doi:10.1016/0006-291X(83)91675-3)

12 Kennedy BP, Marsden JJ, Flynn TG, de Bold AJ \& Davies PL. Isolation and nucleotide sequence of a cloned cardionatrin cDNA. Biochemical and Biophysical Research Communications 1984122 1076-1082. (doi:10.1016/0006-291X(84)91201-4)

13 Kangawa K \& Matsuo H. Purification and complete amino acid sequence of $\alpha$-human atrial natriuretic polypeptide ( $\alpha$-hANP). Biochemical and Biophysical Research Communications 1984118 131-139. (doi:10.1016/0006-291X(84)91077-5)

14 de Bold AJ. Tissue fractionation studies on the relationship between an atrial natriuretic factor and specific atrial granules. Canadian Journal of Physiology and Pharmacology $198260324-330$. (doi:10.1139/y82-045)

15 de Bold ML \& de Bold AJ. Immunocytochemical demonstration of cardionatrins in human atrial myocardium. In Immunocytochemistry in Tumor Diagnosis. Ed J Russo. Boston, MA, USA: Martinus Nijhoss Publishing, 1985.

16 de Bold AJ \& Salerno TA. Natriuretic activity of extracts obtained from hearts of different species and from various rat tissues. Canadian Journal of Physiology and Pharmacology 198361 127-130. (doi:10.1139/ y83-018)

17 Hirata Y, Takata S, Kawahara Y, Takai Y, Chino N, Kimura T \& Sakakibara S. Molecular mechanism of action by atrial natriuretic peptide in rat vascular smooth muscle cells. Japanese Circulation Journal 198852 1430-1435. (doi:10.1253/jcj.52.1430)

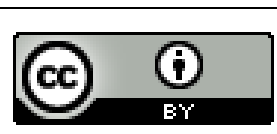


18 Sudoh T, Kangawa K, Minamino N \& Matsuo H. A new natriuretic peptide in porcine brain. Nature 1988332 78-81. (doi:10.1038/ 332078a0)

19 Nakamura S, Naruse M, Naruse K, Kawana M, Nishikawa T, Hosoda S, Tanaka I, Yoshimi T, Yoshihara I, Inagami T et al. Atrial natriuretic peptide and brain natriuretic peptide coexist in the secretory granules of human cardiac myocytes. American Journal of Hypertension 19914 909-912. (doi:10.1093/ajh/4.2.113)

20 Kojima M, Minamino N, Kangawa K \& Matsuo H. Cloning and sequence analysis of a cDNA encoding a precursor for rat C-type natriuretic peptide (CNP). FEBS Letters 1990276 209-213. (doi:10.1016/0014-5793(90)80544-S)

21 Komatsu Y, Nakao K, Suga S, Ogawa Y, Mukoyama M, Arai H, Shirakami G, Hosoda K, Nakagawa O, Hama N et al. C-type natriuretic peptide (CNP) in rats and humans. Endocrinology 1991129 1104-1106. (doi:10.1210/endo-129-2-1104)

22 Casco VH, Veinot JP, Kuroski de Bold ML, Masters RG, Stevenson MM $\&$ de Bold AJ. Natriuretic peptide system gene expression in human coronary arteries. Journal of Histochemistry and Cytochemistry $2002 \mathbf{5 0}$ 799-809. (doi:10.1177/002215540205000606)

23 Takahashi T, Allen PD \& Izumo S. Expression of A-, B-, and C-type natriuretic peptide genes in failing and developing human ventricles. Correlation with expression of the $\mathrm{Ca}^{2+}$-ATPase gene. Circulation Research 199271 9-17. (doi:10.1161/01.RES.71.1.9)

24 Del RS, Cabiati M, Vozzi F, Battolla B, Caselli C, Forini F, Segnani C, Prescimone T, Giannessi D \& Mattii L. Expression of C-type natriuretic peptide and its receptor NPR-B in cardiomyocytes. Peptides 201132 1713-1718. (doi:10.1016/j.peptides.2011.06.014)

25 Sagnella GA. Measurement and significance of circulating natriuretic peptides in cardiovascular disease. Clinical Science 199895 519-529. (doi:10.1042/CS19980144)

26 Rademaker MT \& Richards AM. Cardiac natriuretic peptides for cardiac health. Clinical Science 2005108 23-36. (doi:10.1042/CS20040253)

27 Gardner DG, Vlasuk GP, Baxter JD, Fiddes JC \& Lewicki JA. Identification of atrial natriuretic factor gene transcripts in the central nervous system of the rat. PNAS 198784 2175-2179. (doi:10.1073/ pnas.84.8.2175)

28 Ogawa T, Linz W, Stevenson M, Bruneau BG, Kuroski de Bold ML, Chen JH, Eid H, Scholkens BA \& de Bold AJ. Evidence for loaddependant and load-independant determinants of cardiac natriuretic peptide production. Circulation 199693 2059-2067. (doi:10.1161/ 01.CIR.93.11.2059)

29 Ruskoaho H. Cardiac hormones as diagnostic tools in heart failure. Endocrine Reviews 200324 341-356. (doi:10.1210/er.2003-0006)

30 Masters RG, Davies RA, Keon WJ, Walley VM, Koshal A \& de Bold AJ. Neuroendocrine response to cardiac transplantation. Canadian Journal of Cardiology 19939 609-617.

31 Masters RG, Davies RA, Veinot JP, Hendry PJ, Smith SJ \& de Bold AJ. Discoordinate modulation of natriuretic peptides during acute cardiac allograft rejection in humans. Circulation 1999100 287-291. (doi:10.1161/01.CIR.100.3.287)

32 Yokota N, Bruneau BG, Fernandez BE, Kuroski de Bold ML, Piazza LA, Eid H \& de Bold AJ. Dissociation of cardiac hypertrophy, myosin heavy chain isoform expression, and natriuretic peptide production in DOCA-salt rats. American Journal of Hypertension 19958 301-310. (doi:10.1016/0895-7061(94)00210-3)

33 Mukoyama M, Nakao K, Hosoda K, Suga S, Saito Y, Ogawa Y, Shirakami G, Jougasaki M, Obata K \& Yasue H. Brain natriuretic peptide as a novel cardiac hormone in humans. Evidence for an exquisite dual natriuretic peptide system, atrial natriuretic peptide and brain natriuretic peptide. Journal of Clinical Investigation 199187 1402-1412. (doi:10.1172/JCI115146)

34 Bianciotti LG \& de Bold AJ. Modulation of cardiac natriuretic peptide gene expression following endothelin type A receptor blockade in renovascular hypertension. Cardiovascular Research 200149 808-816. (doi:10.1016/S0008-6363(00)00311-4)
35 Murakami Y, Shimada T, Inoue S, Shimizu H, Ohta Y, Katoh H, Nakamura K \& Ishibashi Y. New insights into the mechanism of the elevation of plasma brain natriuretic polypeptide levels in patients with left ventricular hypertrophy. Canadian Journal of Cardiology 2002 18 1294-1300.

36 Ogawa T, Vatta M, Bruneau BG \& de Bold AJ. Characterization of natriuretic peptide production by adult heart atria. American Journal of Physiology. Heart and Circulatory Physiology 1999276 H1977-H1986.

37 Bruneau BG \& de Bold AJ. Selective changes in natriuretic peptide and early response gene expression in isolated rat atria following stimulation by stretch or endothelin-1. Cardiovascular Research 1994 28 1519-1525. (doi:10.1093/cvr/28.10.1519)

38 Bruneau BG, Piazza LA \& de Bold AJ. $\alpha 1$-adrenergic stimulation of isolated rat atria results in discoordinate increases in natriuretic peptide secretion and gene expression and enhances Egr-1 and c-Myc expression. Endocrinology 1996137 137-143.

39 Bruneau BG, Piazza LA \& de Bold AJ. BNP gene expression is specifically modulated by stretch and ET- 1 in a new model of isolated rat atria. American Journal of Physiology 1997273 H2678-H2686.

40 Mangat $\mathrm{H} \&$ de Bold AJ. Stretch-induced atrial natriuretic factor release utilizes a rapidly depleting pool of newly synthesized hormone. Endocrinology 1993133 1398-1403.

41 Arvan P, Kuliawat R, Prabakaran D, Zavacki AM, Elahi D, Wang S \& Pilkey D. Protein discharge from immature secretory granules displays both regulated and constitutive characteristics. Journal of Biological Chemistry 1991266 14171-14174.

42 Eguchi S, Hirata Y, Imai T \& Marumo F. Endothelin receptor subtypes are coupled to adenylate cyclase via different guanyl nucleotidebinding proteins in vasculature. Endocrinology 1993132 524-529.

43 Hilal-Dandan R, Ramirez MT, Villegas S, Gonzalez A, EndoMochizuki Y, Brown JH \& Brunton LL. Endothelin $\mathrm{ET}_{\mathrm{A}}$ receptor regulates signaling and ANF gene expression via multiple $G$ proteinlinked pathways. American Journal of Physiology 1997272 H130-H137.

44 de Bold AJ, Ma KK, Zhang Y, de Bold ML, Bensimon M \& Khoshbaten A. The physiological and pathophysiological modulation of the endocrine function of the heart. Canadian Journal of Physiology and Pharmacology 200179 705-714. (doi:10.1139/y01-038)

45 Kyosseva SV. Mitogen-activated protein kinase signaling. International Review of Neurobiology 200459 201-220.

46 Bensimon M, Chang A, Kuroski-de Bold ML, Ponce A, Carreras D \& de Bold AJ. Participation of $G$ proteins in natriuretic peptide hormone secretion from heart atria. Endocrinology 2004145 5313-5321. (doi:10.1210/en.2004-0698)

47 Pratley RE, Nauck M, Bailey T, Montanya E, Cuddihy R, Filetti S, Thomsen AB, Sondergaard RE \& Davies M. Liraglutide versus sitagliptin for patients with type 2 diabetes who did not have adequate glycaemic control with metformin: a 26-week, randomised, parallelgroup, open-label trial. Lancet 2010375 1447-1456. (doi:10.1016/ S0140-6736(10)60307-8)

48 Russell-Jones D \& Gough S. Recent advances in incretin-based therapies. Clinical Endocrinology 201277 489-499. (doi:10.1111/ j.1365-2265.2012.04483.x)

49 Kim M, Platt MJ, Shibasaki T, Quaggin SE, Backx PH, Seino S, Simpson JA \& Drucker DJ. GLP-1 receptor activation and Epac2 link atrial natriuretic peptide secretion to control of blood pressure. Nature Medicine 201319 567-575. (doi:10.1038/nm.3128)

50 Lowe DG, Chang MS, Hellmiss R, Chen E, Singh S, Garbers DL \& Goeddel DV. Human atrial natriuretic peptide receptor defines a new paradigm for second messenger signal transduction. EMBO Journal 19898 1377-1384.

51 Schulz S, Singh S, Bellet RA, Singh G, Tubb DJ, Chin H \& Garbers DL. The primary structure of a plasma membrane guanylate cyclase demonstrates diversity within this new receptor family. Cell 198958 1155-1162. (doi:10.1016/0092-8674(89)90513-8)

52 Kumar R, Grammatikakis N \& Chinkers M. Regulation of the atrial natriuretic peptide receptor by heat shock protein 90 complexes.

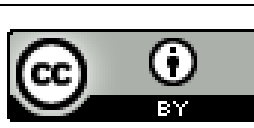


Journal of Biological Chemistry 2001276 11371-11375. (doi:10.1074/ jbc.M010480200)

53 Gerzer R, Witzgall H, Tremblay J, Gutkowska J \& Hamet P. Rapid increase in plasma and urinary cyclic GMP after bolus injection of atrial natriuretic factor in man. Journal of Clinical Endocrinology and Metabolism 198561 1217-1219. (doi:10.1210/jcem-61-6-1217)

54 Lincoln TM \& Cornwell TL. Intracellular cyclic GMP receptor proteins. FASEB Journal 19937 328-338.

55 Lincoln TM, Dey N \& Sellak H. cGMP-dependent protein kinase signaling mechanisms in smooth muscle: from the regulation of tone to gene expression. Journal of Applied Physiology 200191 1421-1430.

56 Lucas KA, Pitari GM, Kazerounian S, Ruiz-Stewart I, Park J, Schulz S, Chepenik KP \& Waldman SA. Guanylyl cyclases and signaling by cyclic GMP. Pharmacological Reviews 200052 375-414.

57 Murthy KS \& Makhlouf GM. Identification of the G protein-activating domain of the natriuretic peptide clearance receptor (NPR-C). Journal of Biological Chemistry 1999274 17587-17592. (doi:10.1074/ jbc.274.25.17587)

58 Cerra MC. Cardiac distribution of the binding sites for natriuretic peptides in vertebrates. [Review]. Cardioscience 19945 215-224.

59 Fuller F, Porter JG, Arfsten AE, Miller J, Schilling JW, Scarborough RM, Lewicki JA \& Schenk DB. Atrial natriuretic peptide clearance receptor. Journal of Biological Chemistry 1988263 9395-9401.

60 Stoupakis G \& Klapholz M. Natriuretic peptides: biochemistry, physiology, and therapeutic role in heart failure. Heart Disease $2003 \mathbf{5}$ 215-223. (doi:10.1097/01.HDX.0000074517.30102.64)

61 McGrath MF \& de Bold AJ. Determinants of natriuretic peptide gene expression. Peptides 200526 933-943. (doi:10.1016/j.peptides.2004. 12.022)

62 McGrath MF, de Bold ML \& de Bold AJ. The endocrine function of the heart. Trends in Endocrinology and Metabolism 200516 469-477. (doi:10.1016/j.tem.2005.10.007)

63 McGrath MF \& de Bold AJ. Transcriptional analysis of the mammalian heart with special reference to its endocrine function. BMC Genomics 200910 254. (doi:10.1186/1471-2164-10-254)

64 Melo LG, Steinhelper ME, Pang SC, Tse Y \& Ackermann U. ANP in regulation of arterial pressure and fluid-electrolyte balance: lessons from genetic mouse models. Physiological Genomics 20003 45-58.

65 Vanderheyden M, Bartunek J \& Goethals M. Brain and other natriuretic peptides: molecular aspects. European Journal of Heart Failure 20046 261-268. (doi:10.1016/j.ejheart.2004.01.004)

66 de Bold AJ \& Bruneau BG. Natriuretic peptides. In Handbook of Physiology, Section 7: The Endocrine System, Volume III: Endocrine Regulation of Water and Electrolyte Balance. Eds JCS Fray \& MH Goodman. American Physiological Society by Oxford University Press, 2000.

67 Tarjan E, Denton DA \& Weisinger RS. Atrial natriuretic peptide inhibits water and sodium intake in rabbits. Regulatory Peptides 1988 23 63-75. (doi:10.1016/0167-0115(88)90422-3)

68 Samson WK. Atrial natriuretic factor inhibits dehydration and hemorrhage-induced vasopressin release. Neuroendocrinology 198540 277-279. (doi:10.1159/000124085)

69 Calderone A, Thaik CM, Takahashi N, Chang DLF \& Colucci WS. Nitric oxide, atrial natriuretic peptide, and cyclic GMP inhibit the growthpromoting effects of norepinephrine in cardiac myocytes and fibroblasts. Journal of Clinical Investigation 1998101 812-818. (doi:10.1172/JCI119883)

70 Tamura N, Ogawa Y, Chusho H, Nakamura K, Nakao K, Suda M, Kasahara M, Hashimoto R, Katsuura G, Mukoyama M et al. Cardiac fibrosis in mice lacking brain natriuretic peptide. PNAS 200097 4239-4244. (doi:10.1073/pnas.070371497)

71 Chusho H, Ogawa Y, Tamura N, Suda M, Yasoda A, Miyazawa T, Kishimoto I, Komatsu Y, Itoh H, Tanaka K et al. Genetic models reveal that brain natriuretic peptide can signal through different tissue-specific receptor-mediated pathways. Endocrinology 2000141 3807-3813.

72 Itoh H, Pratt RE, Ohno M \& Dzau VJ. Atrial natriuretic polypeptide as a novel antigrowth factor of endothelial cells. Hypertension 199219 758-761. (doi:10.1161/01.HYP.19.6.758)

73 Kuhn M. Endothelial actions of atrial and B-type natriuretic peptides. British Journal of Pharmacology 2012166 522-531. (doi:10.1111/j.14765381.2012.01827.x)

74 Franco-Saenz R, Atarashi K, Takagi M \& Mulrow PJ. Effect of atrial natriuretic factor on renin and aldosterone. Journal of Cardiovascular Pharmacology 198913 (Suppl 6) S31-S35. (doi:10.1097/00005344198905006-00010)

75 Brenner BM, Ballermann BJ, Gunning ME \& Zeidel ML. Diverse biological actions of atrial natriuretic peptide. Physiological Reviews 199070 665-699.

76 Burger AJ. A review of the renal and neurohormonal effects of B-type natriuretic peptide. Congestive Heart Failure 200511 30-38. (doi:10. 1111/j.1527-5299.2005.03794.x)

77 Sengenes C, Berlan M, De Glisezinski I, Lafontan M \& Galitzky J. Natriuretic peptides: a new lipolytic pathway in human adipocytes. FASEB Journal 200014 1345-1351. (doi:10.1096/fj.14.10.1345)

78 Sengenes C, Stich V, Berlan M, Hejnova J, Lafontan M, Pariskova Z \& Galitzky J. Increased lipolysis in adipose tissue and lipid mobilization to natriuretic peptides during low-calorie diet in obese women. International Journal of Obesity and Related Metabolic Disorders 200226 24-32. (doi:10.1038/sj.ijo.0801845)

79 Sengenes C, Zakaroff-Girard A, Moulin A, Berlan M, Bouloumie A, Lafontan M \& Galitzky J. Natriuretic peptide-dependent lipolysis in fat cells is a primate specificity. American Journal of Physiology. Regulatory, Integrative and Comparative Physiology 2002283 R257-R265.

80 Sengenes C, Bouloumie A, Hauner H, Berlan M, Busse R, Lafontan M \& Galitzky J. Involvement of a cGMP-dependent pathway in the natriuretic peptide-mediated hormone sensitive lipase phosphorylation in human adipocytes. Journal of Biological Chemistry 2003278 48617-48626. (doi:10.1074/jbc.M303713200)

81 Galitzky J, Sengenes C, Thalamas C, Marques MA, Senard JM, Lafontan M \& Berlan M. The lipid-mobilizing effect of atrial natriuretic peptide is unrelated to sympathetic nervous system activation or obesity in young men. Journal of Lipid Research 200142 536-544.

82 Sarzani R, Marcucci P, Salvi F, Bordicchia M, Espinosa E, Mucci L, Lorenzetti B, Minardi D, Muzzonigro G, Dessi-Fulgheri P et al. Angiotensin II stimulates and atrial natriuretic peptide inhibits human visceral adipocyte growth. International Journal of Obesity 2008 32 259-267. (doi:10.1038/sj.ijo.0803724)

83 Kuroski de Bold ML \& de Bold AJ. Stretch-secretion coupling in atrial cardiocytes. Dissociation between atrial natriuretic factor release and mechanical activity. Hypertension 199118 III-169-III-178. (doi:10. 1161/01.HYP.18.5_Suppl.III169)

84 de Bold AJ, Bruneau BG \& de Bold ML. Mechanical and neuroendocrine regulation of the endocrine heart. Cardiovascular Research 1996 31 7-18. (doi:10.1016/S0008-6363(95)00121-2)

85 Uusimaa PA, Hassinen IE, Vuolteenaho O \& Ruskoaho H. Endothelininduced atrial natriuretic peptide release from cultured neonatal cardiac myocytes: the role of extracellular calcium and protein kinase-C. Endocrinology 1992130 2455-2464.

86 Li Q \& Gardner DG. Negative regulation of the human atrial natriuretic peptide gene by 1,25-dihydroxyvitamin $\mathrm{D}_{3}$. Journal of Biological Chemistry 1994269 4934-4939.

87 Bianciotti LG \& de Bold AJ. Natriuretic peptide gene expression in DOCA-salt hypertension after blockade of type B endothelin receptor. American Journal of Physiology. Heart and Circulatory Physiology 2002 282 H1127-H1134.

88 Ma KK, Ogawa T \& de Bold AJ. Selective upregulation of cardiac brain natriuretic peptide at the transcriptional and translational levels by pro-inflammatory cytokines and by conditioned medium derived from mixed lymphocyte reactions via p38 MAP kinase. Journal of

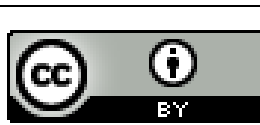

This work is licensed under a Creative Commons Attribution 3.0 Unported License. 
Molecular and Cellular Cardiology 200436 505-513. (doi:10.1016/j. yjmcc.2004.01.001)

89 Ogawa T \& de Bold AJ. Uncoordinated regulation of atrial natriuretic factor and brain natriuretic peptide in lipopolysaccharide-treated rats. Biomarkers 201217 140-149. (doi:10.3109/1354750X.2011.643487)

90 Cowie MR, Struthers AD, Wood DA, Coats AJ, Thompson SG, PooleWilson PA \& Sutton GC. Value of natriuretic peptides in assessment of patients with possible new heart failure in primary care. Lancet 1997 350 1349-1353. (doi:10.1016/S0140-6736(97)06031-5)

91 Foy SG, Crozier IG, Richards AM, Nicholls MG, Turner JG, Frampton CM \& Ikram H. Neurohormonal changes after acute myocardial infarction. Relationships with haemodynamic indices and effects of ACE inhibition. European Heart Journal 199516 770-778.

92 Sagnella GA, Markandu ND, Shore AC \& MacGregor GA. Raised circulating levels of atrial natriuretic peptides in essential hypertension. Lancet 19861 179-181. (doi:10.1016/S0140-6736(86)90653-7)

93 Sagnella GA, Markandu ND, Shore AC \& MacGregor GA. Effects of changes in dietary sodium intake and saline infusion on immunoreactive atrial natriuretic peptide in human plasma. Lancet 19852 1208-1211. (doi:10.1016/S0140-6736(85)90741-X)

94 Buckley MG, Markandu ND, Miller MA, Sagnella GA \& MacGregor GA. Plasma concentrations and comparisons of brain and atrial natriuretic peptide in normal subjects and in patients with essential hypertension. Journal of Human Hypertension 19937 245-250.

95 Nishikimi T, Yoshihara F, Morimoto A, Ishikawa K, Ishimitsu T, Saito Y, Kangawa K, Matsuo H, Omae T \& Matsuoka H. Relationship between left ventricular geometry and natriuretic peptide levels in essential hypertension. Hypertension 199628 22-30. (doi:10.1161/01. HYP.28.1.22)

96 Nagaya N, Nishikimi T, Goto Y, Miyao Y, Kobayashi Y, Morii I, Daikoku S, Matsumoto T, Miyazaki S, Matsuoka H et al. Plasma brain natriuretic peptide is a biochemical marker for the prediction of progressive ventricular remodeling after acute myocardial infarction. American Heart Journal 1998135 21-28. (doi:10.1016/S00028703(98)70338-2)

97 Ramos H \& de Bold AJ. Gene expression, processing and secretion of natriuretic peptides: physiologic and diagnostic implications. Heart Failure Clinics 20062 255-268. (doi:10.1016/j.hfc.2006.08.005)

98 Cody RJ, Atlas SA, Laragh JH, Kubo SH, Covit AB, Ryman KS, Shaknovich A, Pondolfino K, Clark M, Camargo MJ et al. Atrial natriuretic factor in normal subjects and heart failure patients. Plasma levels and renal, hormonal, and hemodynamic responses to peptide infusion. Journal of Clinical Investigation 198678 1362-1374 (doi:10.1172/JCI112723)

99 Pemberton CJ, Johnson ML, Yandle TG \& Espiner EA. Deconvolution analysis of cardiac natriuretic peptides during acute volume overload. Hypertension 200036 355-359. (doi:10.1161/01.HYP.36.3.355)

100 Thuerauf DJ, Hanford DS \& Glembotski CC. Regulation of rat brain natriuretic peptide transcription. A potential role for GATA-related transcription factors in myocardial cell gene expression. Journal of Biological Chemistry 1994269 17772-17775.

101 Hammerer-Lercher A, Neubauer E, Muller S, Pachinger O, Puschendorf B \& Mair J. Head-to-head comparison of N-terminal probrain natriuretic peptide, brain natriuretic peptide and $\mathrm{N}$-terminal pro-atrial natriuretic peptide in diagnosing left ventricular dysfunction. Clinica Chimica Acta 2001310 193-197. (doi:10.1016/S00098981(01)00578-2)

102 Omland T, Aakvaag A, Bonarjee VV, Caidahl K, Lie RT, Nilsen DW, Sundsfjord JA \& Dickstein K. Plasma brain natriuretic peptide as an indicator of left ventricular systolic function and long-term survival after acute myocardial infarction. Comparison with plasma atrial natriuretic peptide and N-terminal proatrial natriuretic peptide. Circulation 199693 1963-1969. (doi:10.1161/01.CIR.93.11.1963)

103 Yamamoto K, Burnett JC Jr, Jougasaki M, Nishimura RA, Bailey KR, Saito Y, Nakao K \& Redfield MM. Superiority of brain natriuretic peptide as a hormonal marker of ventricular systolic and diastolic dysfunction and ventricular hypertrophy. Hypertension $1996 \mathbf{2 8}$ 988-994. (doi:10.1161/01.HYP.28.6.988)

104 Steiner J \& Guglin M. BNP or NTproBNP? A clinician's perspective International Journal of Cardiology 2008129 5-14. (doi:10.1016/j.ijcard. 2007.12.093)

105 Maisel AS, Krishnaswamy P, Nowak RM, McCord J, Hollander JE, Duc P, Omland T, Storrow AB, Abraham WT, Wu AH et al. Rapid measurement of B-type natriuretic peptide in the emergency diagnosis of heart failure. New England Journal of Medicine 2002347 161-167. (doi:10.1056/NEJMoa020233)

106 Wang TJ, Larson MG, Levy D, Benjamin EJ, Leip EP, Omland T, Wolf PA \& Vasan RS. Plasma natriuretic peptide levels and the risk of cardiovascular events and death. New England Journal of Medicine 2004 350 655-663. (doi:10.1056/NEJMoa031994)

107 Nishikimi T, Maeda N \& Matsuoka H. The role of natriuretic peptides in cardioprotection. Cardiovascular Research 200669 318-328. (doi:10.1016/j.cardiores.2005.10.001)

108 Vasan RS, Benjamin EJ, Larson MG, Leip EP, Wang TJ, Wilson PW \& Levy D. Plasma natriuretic peptides for community screening for left ventricular hypertrophy and systolic dysfunction: the Framingham heart study. Journal of the American Medical Association $2002 \mathbf{2 8 8}$ 1252-1259. (doi:10.1001/jama.288.10.1252)

109 Nagaya N, Nishikimi T, Uematsu M, Satoh T, Kyotani S, Sakamaki F, Kakishita M, Fukushima K, Okano Y, Nakanishi N et al. Plasma brain natriuretic peptide as a prognostic indicator in patients with primary pulmonary hypertension. Circulation 2000102 865-870. (doi:10.1161/01.CIR.102.8.865)

110 Morgenthaler NG, Struck J, Thomas B \& Bergmann A. Immunoluminometric assay for the midregion of pro-atrial natriuretic peptide in human plasma. Clinical Chemistry 200450 234-236. (doi:10.1373/ clinchem.2003.021204)

111 Moertl D, Berger R, Struck J, Gleiss A, Hammer A, Morgenthaler NG, Bergmann A, Huelsmann M \& Pacher R. Comparison of midregional pro-atrial and B-type natriuretic peptides in chronic heart failure: influencing factors, detection of left ventricular systolic dysfunction, and prediction of death. Journal of the American College of Cardiology 200953 1783-1790. (doi:10.1016/j.jacc.2009.01.057)

112 Dieplinger B, Gegenhuber A, Kaar G, Poelz W, Haltmayer M \& Mueller T. Prognostic value of established and novel biomarkers in patients with shortness of breath attending an emergency department. Clinical Biochemistry 201043 714-719. (doi:10.1016/j.clinbiochem.2010.02.002)

113 Suwa M, Seino Y, Nomachi Y, Matsuki S \& Funahashi K. Multicenter prospective investigation on efficacy and safety of carperitide for acute heart failure in the 'real world' of therapy. Circulation Journal 200569 283-290. (doi:10.1253/circj.69.283)

114 Nomura F, Kurobe N, Mori Y, Hikita A, Kawai M, Suwa M \& Okutani Y. Multicenter prospective investigation on efficacy and safety of carperitide as a first-line drug for acute heart failure syndrome with preserved blood pressure: COMPASS: Carperitide Effects Observed Through Monitoring Dyspnea in Acute Decompensated Heart Failure Study. Circulation Journal 200872 1777-1786. (doi:10.1253/circj.CJ07-0760)

115 Kitakaze M, Asakura M, Kim J, Shintani Y, Asanuma H, Hamasaki T, Seguchi O, Myoishi M, Minamino T, Ohara T et al. Human atrial natriuretic peptide and nicorandil as adjuncts to reperfusion treatment for acute myocardial infarction (J-WIND): two randomised trials. Lancet 2007370 1483-1493. (doi:10.1016/S01406736(07)61634-1)

116 Morikawa S, Sone T, Tsuboi H, Mukawa H, Morishima I, Uesugi M, Morita Y, Numaguchi Y, Okumura K \& Murohara T. Renal protective effects and the prevention of contrast-induced nephropathy by atrial natriuretic peptide. Journal of the American College of Cardiology 2009 53 1040-1046. (doi:10.1016/j.jacc.2008.10.061)

117 Sackner-Bernstein JD, Skopicki HA \& Aaronson KD. Risk of worsening renal function with nesiritide in patients with acutely decompensated

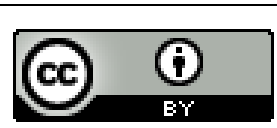


heart failure. Circulation 2005111 1487-1491. (doi:10.1161/01.CIR. 0000159340.93220.E4)

118 O'Connor CM, Starling RC, Hernandez AF, Armstrong PW, Dickstein K, Hasselblad V, Heizer GM, Komajda M, Massie BM, McMurray JJ et al. Effect of nesiritide in patients with acute decompensated heart failure. New England Journal of Medicine 2011 365 32-43. (doi:10.1056/NEJMoa1100171)

119 Chen HH, Glockner JF, Schirger JA, Cataliotti A, Redfield MM \& Burnett JC Jr. Novel protein therapeutics for systolic heart failure: chronic subcutaneous B-type natriuretic peptide. Journal of the American College of Cardiology 201260 2305-2312. (doi:10.1016/j.jacc. 2012.07.056)

120 Wei CM, Heublein DM, Perrella MA, Lerman A, Rodeheffer RJ, McGregor CG, Edwards WD, Schaff HV \& Burnett JC Jr. Natriuretic peptide system in human heart failure. Circulation $1993 \mathbf{8 8}$ 1004-1009. (doi:10.1161/01.CIR.88.3.1004)

121 Del Ry S, Passino C, Maltinti M, Emdin M \& Giannessi D. C-type natriuretic peptide plasma levels increase in patients with chronic heart failure as a function of clinical severity. European Journal of Heart Failure 20057 1145-1148. (doi:10.1016/j.ejheart.2004.12.009)

122 Ueda S, Minamino N, Aburaya M, Kangawa K, Matsukura S \& Matsuo H. Distribution and characterization of immunoreactive porcine C-type natriuretic peptide. Biochemical and Biophysical Research Communications 1991175 759-767. (doi:10.1016/0006291X(91)91631-L)

123 Suga S, Nakao K, Itoh H, Komatsu Y, Ogawa Y, Hama N \& Imura H. Endothelial production of C-type natriuretic peptide and its marked augmentation by transforming growth factor- $\beta$. Possible existence of "vascular natriuretic peptide system". Journal of Clinical Investigation 199290 1145-1149. (doi:10.1172/JCI115933)

124 Horio T, Tokudome T, Maki T, Yoshihara F, Suga S, Nishikimi T, Kojima M, Kawano Y \& Kangawa K. Gene expression, secretion, and autocrine action of C-type natriuretic peptide in cultured adult rat cardiac fibroblasts. Endocrinology 2003144 2279-2284. (doi:10.1210/ en.2003-0128)

125 Del Ry S, Passino C, Emdin M \& Giannessi D. C-type natriuretic peptide and heart failure. Pharmacological Research 200654 326-333. (doi:10.1016/j.phrs.2006.06.011)

126 Kalra PR, Clague JR, Bolger AP, Anker SD, Poole-Wilson PA, Struthers AD \& Coats AJ. Myocardial production of C-type natriuretic peptide in chronic heart failure. Circulation $2003107571-573$. (doi:10.1161/01.CIR.0000047280.15244.EB)

127 Suga S, Itoh H, Komatsu Y, Ogawa Y, Hama N, Yoshimasa T \& Nakao K. Cytokine-induced C-type natriuretic peptide (CNP) secretion from vascular endothelial cells - evidence for CNP as a novel autocrine/ paracrine regulator from endothelial cells. Endocrinology 1993133 3038-3041.

128 Nazario B, Hu RM, Pedram A, Prins B \& Levin ER. Atrial and brain natriuretic peptides stimulate the production and secretion of C-type natriuretic peptide from bovine aortic endothelial cells. Journal of Clinical Investigation 199595 1151-1157. (doi:10.1172/JCI117763)

129 Wiley KE \& Davenport AP. Physiological antagonism of endothelin-1 in human conductance and resistance coronary artery. British Journal of Pharmacology 2001133 568-574. (doi:10.1038/sj.bjp. 0704119)

130 Furuya M, Yoshida M, Hayashi Y, Ohnuma N, Minamino N, Kangawa K \& Matsuo H. C-type natriuretic peptide is a growth inhibitor of rat vascular smooth muscle cells. Biochemical and Biophysical Research Communications 1991177 927-931. (doi:10.1016/ 0006-291X(91)90627-J)

131 Pierkes M, Gambaryan S, Boknik P, Lohmann SM, Schmitz W, Potthast R, Holtwick R \& Kuhn M. Increased effects of C-type natriuretic peptide on cardiac ventricular contractility and relaxation in guanylyl cyclase A-deficient mice. Cardiovascular Research 200253 852-861. (doi:10.1016/S0008-6363(01)00543-0)
132 Brusq JM, Mayoux E, Guigui L \& Kirilovsky J. Effects of C-type natriuretic peptide on rat cardiac contractility. British Journal of Pharmacology 1999128 206-212. (doi:10.1038/sj.bjp.0702766)

133 Beaulieu P, Cardinal R, Page P, Francoeur F, Tremblay J \& Lambert C. Positive chronotropic and inotropic effects of C-type natriuretic peptide in dogs. American Journal of Physiology 1997273 H1933-H1940.

134 Tokudome T, Horio T, Soeki T, Mori K, Kishimoto I, Suga S, Yoshihara F, Kawano Y, Kohno M \& Kangawa K. Inhibitory effect of C-type natriuretic peptide (CNP) on cultured cardiac myocyte hypertrophy: interference between CNP and endothelin-1 signaling pathways. Endocrinology 2004145 2131-2140. (doi:10.1210/ en.2003-1260)

135 Izumiya Y, Araki S, Usuku H, Rokutanda T, Hanatani S \& Ogawa H. Chronic C-type natriuretic peptide infusion attenuates angiotensin II-induced myocardial superoxide production and cardiac remodeling. International Journal of Vascular Medicine 20122012246058. (doi:10.1155/2012/246058)

136 Igaki T, Itoh H, Suga SI, Hama N, Ogawa Y, Komatsu Y, Yamashita J, Doi K, Chun TH \& Nakao K. Effects of intravenously administered C-type natriuretic peptide in humans: comparison with atrial natriuretic peptide. Hypertension Research 199821 7-13. (doi:10.1291/ hypres.21.7)

137 Wei CM, Kao PC, Lin JT, Heublein DM, Schaff HV \& Burnett JC Jr. Circulating $\beta$-atrial natriuretic factor in congestive heart failure in humans. Circulation 199388 1016-1020. (doi:10.1161/01.CIR. 88.3.1016)

138 Kitamura K, Kangawa K, Ishiyama Y, Washimine H, Ichiki Y, Kawamoto M, Minamino N, Matsuo H \& Eto T. Identification and hypotensive activity of proadrenomedullin N-terminal 20 peptide (PAMP). FEBS Letters 1994351 35-37. (doi:10.1016/00145793(94)00810-8)

139 Washimine H, Kitamura K, Ichiki Y, Yamamoto Y, Kangawa K, Matsuo H \& Eto T. Immunoreactive proadrenomedullin N-terminal 20 peptide in human tissue, plasma and urine. Biochemical and Biophysical Research Communications 1994202 1081-1087. (doi:10.1006/bbrc.1994.2039)

140 Kinoshita H, Fujimoto S, Kitamura K, Yokota N, Kawamoto M, Tokura T, Hisanaga S \& Eto T. Plasma and urine levels of adrenomedullin and proadrenomedullin N-terminal 20 peptide in chronic glomerulonephritis. American Journal of Kidney Diseases 1999 34 114-119. (doi:10.1016/S0272-6386(99)70116-2)

141 Hirata Y, Hayakawa H, Suzuki Y, Suzuki E, Ikenouchi H, Kohmoto O, Kimura K, Kitamura K, Eto T, Kangawa K et al. Mechanisms of adrenomedullin-induced vasodilation in the rat kidney. Hypertension 199525 790-795. (doi:10.1161/01.HYP.25.4.790)

142 Ichiki Y, Kitamura K, Kangawa K, Kawamoto M, Matsuo H \& Eto T. Distribution and characterization of immunoreactive adrenomedullin in human tissue and plasma. FEBS Letters 1994338 6-10. (doi:10.1016/0014-5793(94)80106-1)

143 Cormier-Regard S, Nguyen SV \& Claycomb WC. Adrenomedullin gene expression is developmentally regulated and induced by hypoxia in rat ventricular cardiac myocytes. Journal of Biological Chemistry 1998 273 17787-17792. (doi:10.1074/jbc.273.28.17787)

144 Sugo S, Minamino N, Shoji H, Kangawa K, Kitamura K, Eto T \& Matsuo H. Production and secretion of adrenomedullin from vascular smooth muscle cells: augmented production by tumor necrosis factor- $\alpha$. Biochemical and Biophysical Research Communications 1994 203 719-726. (doi:10.1006/bbrc.1994.2241)

145 Sugo S, Minamino N, Kangawa K, Miyamoto K, Kitamura K, Sakata J, Eto T \& Matsuo H. Endothelial cells actively synthesize and secrete adrenomedullin. Biochemical and Biophysical Research Communications 1994201 1160-1166. (doi:10.1006/bbrc.1994.1827)

146 Beltowski J \& Jamroz A. Adrenomedullin - what do we know 10 years since its discovery? Polish Journal of Pharmacology 200456 5-27.

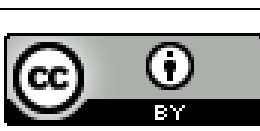


147 McLatchie LM, Fraser NJ, Main MJ, Wise A, Brown J, Thompson N, Solari R, Lee MG \& Foord SM. RAMPs regulate the transport and ligand specificity of the calcitonin-receptor-like receptor. Nature 1998393 333-339. (doi:10.1038/30666)

148 Samson WK. Adrenomedullin and the control of fluid and electrolyte homeostasis. Annual Review of Physiology 199961 363-389. (doi:10.1146/annurev.physiol.61.1.363)

149 Tsuruda T, Kato J, Kitamura K, Kuwasako K, Imamura T, Koiwaya Y, Tsuji T, Kangawa K \& Eto T. Adrenomedullin: a possible autocrine or paracrine inhibitor of hypertrophy of cardiomyocytes. Hypertension 199831 505-510. (doi:10.1161/01.HYP.31.1.505)

150 Kato J, Kitamura K, Matsui E, Tanaka M, Ishizaka Y, Kita T, Kangawa K \& Eto T. Plasma adrenomedullin and natriuretic peptides in patients with essential or malignant hypertension. Hypertension Research 1999 22 61-65. (doi:10.1291/hypres.22.61)

151 Kato J, Kobayashi K, Etoh T, Tanaka M, Kitamura K, Imamura T, Koiwaya Y, Kangawa K \& Eto T. Plasma adrenomedullin concentration in patients with heart failure. Journal of Clinical Endocrinology and Metabolism 199681 180-183.

152 Kobayashi K, Kitamura K, Hirayama N, Date H, Kashiwagi T, Ikushima I, Hanada Y, Nagatomo Y, Takenaga M, Ishikawa T et al. Increased plasma adrenomedullin in acute myocardial infarction. American Heart Journal 1996131 676-680. (doi:10.1016/S00028703(96)90270-7)

153 Hirayama N, Kitamura K, Imamura T, Kato J, Koiwaya Y, Tsuji T, Kangawa K \& Eto T. Molecular forms of circulating adrenomedullin in patients with congestive heart failure. Journal of Endocrinology 1999 160 297-303. (doi:10.1677/joe.0.1600297)

154 Hirata Y, Mitaka C, Sato K, Nagura T, Tsunoda Y, Amaha K \& Marumo F. Increased circulating adrenomedullin, a novel vasodilatory peptide, in sepsis. Journal of Clinical Endocrinology and Metabolism 199681 1449-1453.

155 Kuwasako K, Kitamura K, Kangawa K, Ishiyama Y, Kato J \& Eto T. Increased plasma proadrenomedullin $\mathrm{N}$-terminal 20 peptide in patients with essential hypertension. Annals of Clinical Biochemistry 199936 622-628. (doi:10.1177/000456329903600510)

156 Shimosawa T \& Fujita T. Hypotensive effect of a newly identified peptide, proadrenomedullin N-terminal 20 peptide. Hypertension 1996 28 325-329. (doi:10.1161/01.HYP.28.3.325)

157 Kamohara M, Matsuo A, Takasaki J, Kohda M, Matsumoto M, Matsumoto S, Soga T, Hiyama H, Kobori M \& Katou M. Identification of MrgX2 as a human G-protein-coupled receptor for proadrenomedullin N-terminal peptides. Biochemical and Biophysical Research Communications 2005330 1146-1152. (doi:10.1016/j.bbrc.2005 03.088)

158 Kato J, Tsuruda T, Kitamura K \& Eto T. Adrenomedullin: a possible autocrine or paracrine hormone in the cardiac ventricles. Hypertension Research 200326 (Suppl) S113-S119. (doi:10.1291/hypres.26.S113)

159 Eto T, Kitamura K \& Kato J. Biological and clinical roles of adrenomedullin in circulation control and cardiovascular diseases. Clinical and Experimental Pharmacology and Physiology 199926 371-380. (doi:10.1046/j.1440-1681.1999.03047.x)

160 Matsui E, Kitamura K, Yoshida M, Kato J, Asada Y, Sumiyoshi A \& Eto T. Biosynthesis and secretion of adrenomedullin and proadrenomedullin N-terminal 20 peptide in a rat model of endotoxin shock. Hypertension Research 200124 543-549. (doi:10.1291/hypres.24.543)

161 Yanagisawa M, Kurihara H, Kimura S, Tomobe Y, Kobayashi M, Mitsui Y, Yazaki Y, Goto K \& Masaki T. A novel potent vasoconstrictor peptide produced by vascular endothelial cells. Nature 1988332 411-415. (doi:10.1038/332411a0)

162 Yanagisawa M \& Masaki T. Endothelin, a novel endothelium-derived peptide. Pharmacological activities, regulation and possible roles in cardiovascular control. Biochemical Pharmacology 198938 1877-1883. (doi:10.1016/0006-2952(89)90484-X)
163 Yanagisawa M \& Masaki T. Molecular biology and biochemistry of the endothelins. Trends in Pharmacological Sciences 198910 374-378. (doi:10.1016/0165-6147(89)90011-4)

164 Masaki T. The discovery of endothelins. Cardiovascular Research 1998 39 530-533. (doi:10.1016/S0008-6363(98)00153-9)

165 Davenport AP, Ashby MJ, Easton P, Ella S, Bedford J, Dickerson C, Nunez DJ, Capper SJ \& Brown MJ. A sensitive radioimmunoassay measuring endothelin-like immunoreactivity in human plasma: comparison of levels in patients with essential hypertension and normotensive control subjects. Clinical Science 199078 261-264.

166 Wei CM, Lerman A, Rodeheffer RJ, McGregor CG, Brandt RR, Wright S, Heublein DM, Kao PC, Edwards WD \& Burnett JC Jr. Endothelin in human congestive heart failure. Circulation 199489 1580-1586. (doi:10.1161/01.CIR.89.4.1580)

167 Sakurai T, Yanagisawa M, Inoue A, Ryan US, Kimura S, Mitsui Y, Goto $\mathrm{K} \&$ Masaki T. cDNA cloning, sequence analysis and tissue distribution of rat preproendothelin-1 mRNA. Biochemical and Biophysical Research Communications 1991175 44-47. (doi:10.1016/ S0006-291X(05)81197-0)

168 Wong WH, Wong BP, Wong EF, Huang MH \& Wong NL. Downregulation of endothelin B receptors in cardiomyopathic hamsters Cardiology 199889 195-201. (doi:10.1159/000006787)

169 Ishikawa T, Yanagisawa M, Kimura S, Goto K \& Masaki T. Positive inotropic action of novel vasoconstrictor peptide endothelin on guinea pig atria. American Journal of Physiology 1988255 H970-H973.

170 Horio T, Kohno M \& Takeda T. Cosecretion of atrial and brain natriuretic peptides stimulated by endothelin-1 from cultured rat atrial and ventricular cardiocytes. Metabolism 199342 94-96. (doi:10.1016/0026-0495(93)90178-Q)

171 Suzuki E, Hirata Y, Kohmoto O, Sugimoto T, Hayakawa $\mathrm{H}_{\text {, }}$ Matsuoka H, Kojima M, Kangawa K, Minamino N \& Matsuo H. Cellular mechanisms for synthesis and secretion of atrial natriuretic peptide and brain natriuretic peptide in cultured rat atrial cells. Circulation Research 199271 1039-1048. (doi:10.1161/01.RES.71. 5.1039)

172 Haendler B, Hechler U \& Schleuning WD. Molecular cloning of human endothelin (ET) receptors ETA and ETB. Journal of Cardiovascular Pharmacology 199220 (Suppl 12) S1-S4. (doi:10.1097/ 00005344-199204002-00002)

173 Luscher TF \& Barton M. Endothelins and endothelin receptor antagonists: therapeutic considerations for a novel class of cardiovascular drugs. Circulation 2000102 2434-2440. (doi:10.1161/01.CIR. 102.19.2434)

174 Maeda S, Miyauchi T, Sakai S, Kobayashi T, Iemitsu M, Goto K, Sugishita Y \& Matsuda M. Prolonged exercise causes an increase in endothelin-1 production in the heart in rats. American Journal of Physiology 1998275 H2105-H2112.

175 Barton M, Shaw S, d'Uscio LV, Moreau P \& Luscher TF. Angiotensin II increases vascular and renal endothelin-1 and functional endothelin converting enzyme activity in vivo: role of ETA receptors for endothelin regulation. Biochemical and Biophysical Research Communications 1997238 861-865. (doi:10.1006/bbrc.1997.7394)

176 Corder R, Carrier M, Khan N, Klemm P \& Vane JR. Cytokine regulation of endothelin-1 release from bovine aortic endothelial cells. Journal of Cardiovascular Pharmacology 199526 (Suppl 3) S56-S58. (doi:10.1097/ 00005344-199506263-00018)

177 Matsuura A, Yamochi W, Hirata K, Kawashima S \& Yokoyama M. Stimulatory interaction between vascular endothelial growth factor and endothelin-1 on each gene expression. Hypertension 199832 89-95. (doi:10.1161/01.HYP.32.1.89)

178 Boulanger C \& Luscher TF. Release of endothelin from the porcine aorta. Inhibition by endothelium-derived nitric oxide. Journal of Clinical Investigation 199085 587-590. (doi:10.1172/JCI114477)

179 Fujisaki H, Ito H, Hirata Y, Tanaka M, Hata M, Lin M, Adachi S, Akimoto H, Marumo F \& Hiroe M. Natriuretic peptides inhibit angiotensin II-induced proliferation of rat cardiac fibroblasts by

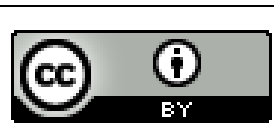

This work is licensed under a Creative Commons Attribution 3.0 Unported License. 
blocking endothelin-1 gene expression. Journal of Clinical Investigation 199596 1059-1065. (doi:10.1172/JCI118092)

180 Wada A, Tsutamato T, Maeda Y, Kanamori T, Matsuda Y \& Kinoshita M. Endogenous atrial natriuretic peptide inhibits endothelin-1 secretion in dogs with severe congestive heart failure. American Journal of Physiology $19962 \mathbf{2 7 0}$ H1819-H1824.

181 McMurray JJ, Ray SG, Abdullah I, Dargie HJ \& Morton JJ. Plasma endothelin in chronic heart failure. Circulation 199285 1374-1379. (doi:10.1161/01.CIR.85.4.1374)

182 Stewart DJ, Kubac G, Costello KB \& Cernacek P. Increased plasma endothelin-1 in the early hours of acute myocardial infarction. Journal of the American College of Cardiology 199118 38-43. (doi:10.1016/S0735-1097(10)80214-1)

183 Giaid A, Yanagisawa M, Langleben D, Michel RP, Levy R, Shennib H, Kimura S, Masaki T, Duguid WP \& Stewart DJ. Expression of endothelin-1 in the lungs of patients with pulmonary hypertension. New England Journal of Medicine 1993328 1732-1739. (doi:10.1056/ NEJM199306173282402)

184 Schulz-Knappe P, Forssmann K, Herbst F, Hock D, Pipkorn R \& Forssmann WG. Isolation and structural analysis of "urodilatin":, a new peptide of the cardiodilatin-(ANP)-family, extracted from human urine. Klinische Wochenschrift 198866 752-759. (doi:10.1007/BF01726570)
185 Aburaya M, Hino J, Minamino N, Kangawa K \& Matsuo H. Isolation and identification of rat brain natriuretic peptides in cardiac atrium. Biochemical and Biophysical Research Communications 1989163 226-232. (doi:10.1016/0006-291X(89)92125-6)

186 Seilhamer JJ, Arfsten A, Miller JA, Lundquist P, Scarborough RM \& Lewicki JA. Human and canine gene homologs of porcine brain natriuretic peptide. Biochemical and Biophysical Research Communications 1989165 650-658. (doi:10.1016/S0006-291X (89)80015-4)

187 Sudoh T, Maekawa K, Kojima M, Minamino N, Kangawa K \& Matsuo H. Cloning and sequence analysis of cDNA encoding a precursor for human brain natriuretic peptide. Biochemical and Biophysical Research Communications 1989159 1427-1434. (doi:10.1016/0006-291X(89)92269-9)

188 Steinhelper ME. Structure, expression, and genomic mapping of the mouse natriuretic peptide type-B gene. Circulation Research 199372 984-992. (doi:10.1161/01.RES.72.5.984)

189 Tawaragi Y, Fuchimura K, Nakazato H, Tanaka S, Minamino N, Kangawa K \& Matsuo H. Gene and precursor structure of porcine C-type natriuretic peptide. Biochemical and Biophysical Research Communications 1990172 627-632. (doi:10.1016/0006291X(90)90720-8)

Received in final form 16 February 2014

Accepted 21 February 2014 http://www.endocrineconnections.org DOI: 10.1530/EC-14-0012
(C) 2014 The authors Published by Bioscientifica Ltd

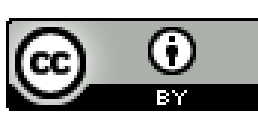

This work is licensed under a Creative Commons Attribution 3.0 Unported License. 